\title{
An atypical localization of lipoma
}

\section{Selma El Kadiri, Sara Elloudi, Rhizlane Chaoui, Zakia Douhi, Hanane Bay Bay, Fatima Zahra Mernissi}

\author{
Department of Dermatology and Venerology, University Hospital Hassan II, Fez, Morocco
}

Corresponding author: Dr. Selma El Kadiri, E-mail: elkadiri-s@hotmail.com

Sir,

Lipomas are the most common benign soft-tissue tumors found in the body. Their localization in the foot is rare [1]. We present an atypical localization of lipoma.

A 48-year-old male presented to our department with a complaint of a mass of the bottom of his right foot. He reported that the mass has been present for approximately 10 years. He didn't report any previous episode of trauma. His medical history was unremarkable. Clinical examination revealed a firm, subcutaneous, well-circumscribed, 4 X $3 \mathrm{~cm}$ mass on the medial plantar area of the right foot. The mass was no pulsatile and freely mobile to underlying structures (Fig. 1). Ultrasound revealed a fatty lass underneath the plantar aponeurosis. The mass was excised and a yellow gelatinous tumor was removed. Histological examination of biopsy specimens revealed lobules of mature adipose tissue typically circumscribed and encapsulated. No recurrence has occurred after 6 months.

Lipomas are benign tumors accounting for 16\% of all soft tissue tumors in the body. The foot is rarely affected by lipomas. Moreover, most reported cases are in the peri malleolar area [1].

Lipomas are usually asymptomatic unless they apply pressure to adjacent sensitive tissue [2].

Different subtypes were described depending on the presence of other components, such as cartilage (chondrolipoma), bone (osteolipoma), muscle (myolipoma), vascular proliferation(angiolipoma) or abundant myxoid changes (myxolipoma). The

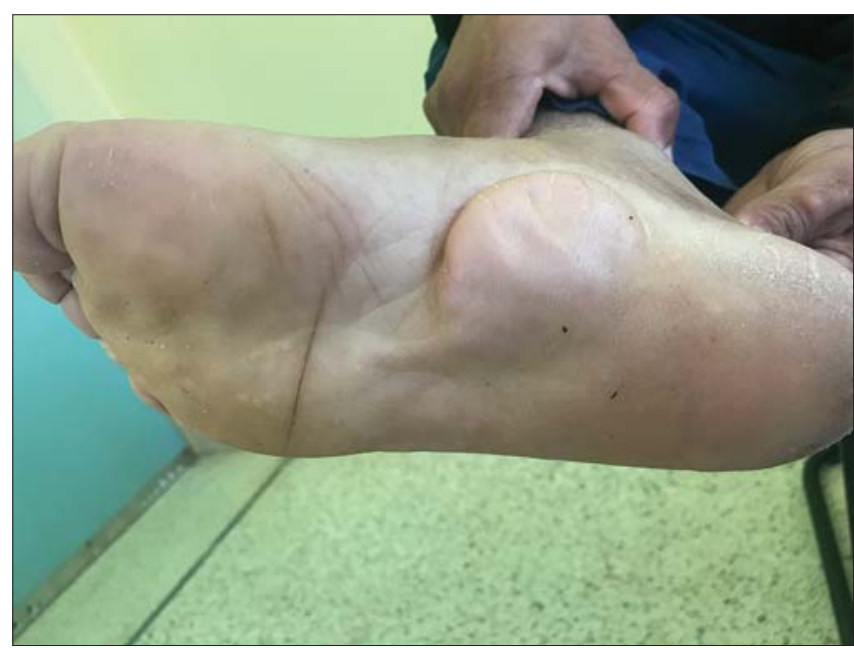

Figure 1: Clinical image showing a subcutaneous, subcutaneous well-circumscribed, $4 \times 3 \mathrm{~cm}$ mass on the medial plantar area of the right foot.

combination of these elements present in the same tumor led to other terms like angiomyolipoma [3]. This case report presented a rare form of lipoma which affected the medial plantar area. This rare should be considered in the differential diagnosis and histopathology should help in the diagnosis. Lipofibroma and lipoblastoma are the main differential diagnosis to consider in this localization with different prognosis [4].

\section{Consent}

The examination of the patient wasconductedaccording to the Declaration of Helsinki principles.

The authorscertifythatthey have obtained all appropriate patient consent forms. In the form the patient(s) has/have givenhis/her/their consent for his/her/their images and otherclinical information to bereported in the journal. The patients understandthattheirnames and initialswill not bepublished and due efforts willbe made to concealtheiridentity, but anonymitycannotbeguaranteed.

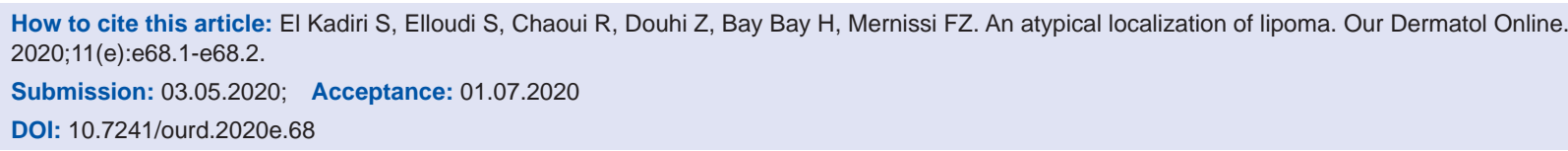


www.odermatol.com

\section{REFERENCES}

1. Taweel NR, Raikin SM. Heel Lipoma Mimicking Plantar Fasciitis in a Ballroom Dancer. J Foot Ankle Sur. 2015;54:251-3.

2. Azevedo CP, Casanova JM, Guerra MG, Santos AL, Portela MI, Tavares PF. Tumors of the foot and ankle: a single-institution experience. J Foot Ankle Surg. 2013;52:147-52.

3. Azevedo CP, Casanova JM, Guerra MG, Santos AL, Portela MI, Tavares PF. Tumors of the foot and ankle: a single-institution experience. J Foot Ankle Surg. 2013;52:147-52.
4. Yeo ED, Chung BM, Kim EJ, Kim WT. Infiltrating angiolipoma of the foot: magnetic resonance imaging features and review of the literature. Skeletal Radiol. 2018;47:859-64.

Copyright by Selma El Kadiri, et al. This is an open access article distributed under the terms of the Creative Commons Attribution License, which permits unrestricted use, distribution, and reproduction in any medium, provided the original author and source are credited.

Source of Support: Nil, Conflict of Interest: None declared. 